\title{
LIVING WITH TERROR NOT LIVING IN TERROR: RELIGIOUS FACTORS AFFECTING PEACE IN PAKISTANI AREAS OF SECTARIAN VIOLENCE
} Madad Ali ${ }^{1}$, Seema Zubair ${ }^{2}$, Aman Ullah ${ }^{3 *}$, Mahrukh Shakir ${ }^{4}$, Maryam ${ }^{5}$, Sadaf Kalsoom Khattak ${ }^{6}$

${ }^{1}$ School of Public Affairs of Science and Technology of China, Hefei, Anhui Province, China; ${ }^{2}$ Lecturer, Department of

Maths State and Computer Science, University of Agriculture, Peshawar, Pakistan; ${ }^{3 *}$ Head of Department/Lecturer, Department of Sociology, University of Swabi, Swabi, Khyber-Pakhtunkhwa, Pakistan; ${ }^{4}$ University of Southampton, United Kingdom; ${ }^{5}$ Lecturer, Department of Psychology, Women University of Swabi, Swabi, Khyber-Pakhtunkhwa, Pakistan; ${ }^{6}$ The University of Agriculture, Peshawar, Pakistan.

Email: ${ }^{1}$ ali12@mail.ustc.edu.cn, ${ }^{2}$ seemazubair@aup.edu.pk, ${ }^{3 *}$ aman@uoswabi.edu.pk, ${ }^{4} \mathrm{~ms} 12 \mathrm{~g} 12 @$ southamptonalumni.ac.uk, ${ }^{5}$ yaqoobmaryam2@gamil.com, ${ }^{6}$ sadafktk777@gmail.com Article History: Received on $4^{\text {th }}$ March 2021, Revised on $27^{\text {th }}$ April 2021, Published on $3^{\text {rd }}$ May 2021

\section{Abstract}

Problem and aim of the study: This study is set out to investigate the impact of misinterpretation of religious education on sectarian violence in District Hangu.

Research methods: Primary data regarding religious education and its role in sectarian violence was collected through a semi-structured questionnaire. The sample size of 279 respondents from three selected villages of District Hangu was randomly selected through the proportional allocation method. The level of significant relationship of the study variables was determined through the Chi-Square test at the Bivariate level analysis. At the multivariate level analysis sect and education were used as controlled variables.

Results: Results show that religious education has a significant role in generating sectarian violence as the observed value of $x^{2}=27.617$ as strongly significant at a $1 \%$ level of significance. Moreover, the findings of the study revealed the relationship between madrasas' education and sectarian violence as significant $(P=\leq 0.05)$ for both groups i.e., literate, and illiterate.

Application of the study: This empirical work is useful in policy planning for the institutionalism of religion. Notwithstanding, a policy for formal registration of all religious madrassas is the need of the day. The present study highlights that extremist literature should be banned in madrassas and there should be a proper syllabus for these institutions. The uniformity of religious education including modern education in their syllabus might be beneficial in this regard. Further, it is needed to focus on the development of underdeveloped areas of Pakistan and encourage cross religion and sects' dialogue.

Originality and Novelty of the study: In Pakistan, the phenomena of sectarian violence have received limited attention in the literature. The existing empirical work in this area is primarily concerned with the political and social aspects of sectarian violence. Thus, the present study contributes to the existing body of knowledge by empirically exploring the issue of sectarian violence from a religious perspective. In this study, a novel method has been applied to determine the impact of religious education on sectarian violence by controlling the background variables of sect and education of the study participants. Such an application of the novel method is believed to enhance the validity of this study and vividly expose the role of sects in the sectarian violence in the research site.

Keywords: Religion, Education, Violence, Sectarian, Conflict.

\section{INTRODUCTION}

Sectarianism is, undoubtedly, as old as human history. It occurs in every society bearing different shapes. In every nation, sectarianism happens to be a complex issue. It varies in its nature and intensity in various cultures and societies. The country Pakistan is the worst victim of sectarianism which proved to impede in the way of its development and countrywide integration. Before starting an in-depth discussion, we consider it important to first define the terms 'sectarianism' and 'sect'. Sectarianism is defined as the extremist behavior, narrow-mindedness, and bloody violence, practiced by sectarian groups towards one another. In sociological terms, the 'sect' is the religious group that segregates from religion based on a specific doctrine (Roberts \& Yamane, 2015; $\underline{\text { Shah, 2014). }}$

The religion of Islam bears seventy-two different sects of which the two are the most prominent: "Shia and Sunni". However, the followers of Shia are considered to be the companion of Ali (A.S), the son-in-law of the Prophet (S.A.W), and the fourth caliph of Islam (Khalili, 2014). Sectarianism is an evil that promotes bloody violence in countries that comprises multiple societies. Sectarianism believes in a non-compromising attitude. It stresses an individual or a group to follow a particular sect or religion, develops the feeling of complacency, and adopts an attitude of intolerance towards other sects of the same religion (Berger, 1954; V. R. Nasr, 2000; Phillips, 2015; Zaman, 1998). 
Sectarianism in Pakistan is a complex phenomenon and it is not easy to analyze the basic factors of the conflict among sects that hinders peace settlement in the state. Before 1980, no such conflict was evidenced among sects. Everything was functioning smoothly having strong cooperation, coordination, integration, harmony in the whole state. However, the situation badly changed after 1980 into violence, non-cooperation, and finally no peace in the society. The whole state came under the shadow of dangerous rumors. People got extremely conscious regarding the security of their lives, and assets. Nothing remained safe at that time. Some people blamed the city of Jhang, as the emergence of sectarianism is the product of migrated Sunni group from that city who preached their specific ideology which further sparked the heinous evil of sectarian violence in Pakistan. In 1980, the first sectarian conflict arose in Jhang city, which took a start with the killing of one religious leader. The Jhang city is divided into two communities: Shia and Sunni, where the former were landlords and the latter, landless (Mahsood \& Muhammad, 2017). As a result, the first insurgent group emerged with the name of Sipah-eSahaba Pakistan (SSP) lead by religious clerics and funded by local businessmen and drug smugglers. They were also involved in giving specialized training to their members for killing the opposite sects. Landlords, on the other side, came up with a resistance group titled Sipah Muhammad Pakistan (SMP).

History of sectarianism depicts that after two years, in 1982, claiming the same agenda of SSP, a third insurgent group emerged with the name of Lashkar-e-Jhangvi (LUJ) which further deteriorated the peaceful environment in the city of Jhang (Ali, 2000). From 1990 till 1992, with the emergence of dictatorship, major changes occurred in the machinery of the state, which supported the cause of these insurgent groups. With such huge support, insurgent groups entered politics and gained huge power and authority in the state. From that time till to date, the whole state came under the clutches of sectarianism. Every sect established its own religious political party like JUI (F), SUC, JUI, STP, MWM, etc., representing their own agendas. This brief history of sectarianism in Pakistan shows that how sectarian conflict contributed to the promotion of violence in the country (Ahmed, 2013; Grare, 2007; Mahsood \& Muhammad, 2017; V. R. Nasr, 2000; Shah, 2014).

\section{The rationale of the study}

The history of the world witnessed religion as the most important institution of the society which socialize its followers as regards its specific values, providing them a complete code of life. In the current scenario, every religion is divided into different sects, which further develops its ideology and rituals. The emergence of unique ideologies further produces great differences based on their differences in beliefs, norms, values, rituals, and perspectives on life. Differences in identities of every sect created much vulnerability. They try hard to become dominant and enforce their ideology in society for gaining political and economic power. Currently, the whole Islamic world is divided into various sects who do not fight only for religion, but political and economic interests are the main motives behind the scene (Mahsood \& Muhammad, 2017).

Thus, the present study aimed to assert that misinterpretation of religious education contributes to sectarian violence in the research site.

\section{LITERATURE REVIEW}

In Pakistan, nearly 95\% of the population is a follower of Islam. Besides people of Pakistan are mostly followers of different sects (Ullah et al., 2020). Affiliation with different sects often contributed to sectarian-based violence, for example, a recent study argued that the incident of sectarian violence and attack on religious places along with sectarian minorities has surged in Pakistan. Nearly about 3059 incidents of sectarian violence have occurred since 1989 in which more than 5000 people were killed (Bakhsh et al., 2020). Due to this uncertain situation, the state has failed to maintain a law-and-order situation, especially in the sectarian-based areas of Pakistan. Sufi shrines, Mosques, and Madrassas are continuously targeted by sectarian extremists (Naaz, 2019). Several socio-political and religious factors are responsible for sectarian violence in Pakistan (Grare, 2007). For instance, an empirical study conducted by Khan and Chaudhry (2011) in district Jhang explored that the sure cause of sectarian-based conflict among Shia and Deobandi is political power. It is also observed that national and international political leaders also support sectarian extremists in Pakistan (Abbas \& Syed, 2020; Khan, 2016; Naaz, 2019). Taken together with the above empirical studies, it could be inferred that in Pakistani society, religion is used as a tool for gaining political power by the elite segments of the society. As said by Smith (2014), [that religion undoubtedly plays an important role in mobilizing the local community for any collective action. Furthermore, Islamisation, the Islamic revolution in Iran, and the Afghan war are some of the contributing factors in the emergence of sectarian violence (Abou Zahab, 2002; Ahmad, 1997). Also, Lynch (2013) has the same view that the increase of sectarianism in the Middle East is the outcome of identity politics, in which politicians take advantage of sectarian differences for "cynical purposes". Similarly, prior studies also evidenced that the intolerance and hatred attitude of religious institutions and leaders against each other's sects significantly upsurged sectarianism(Bakhsh et al., 2020; Grare, 2007; Naaz, 2019).

\section{MATERIALS AND METHODS}

This research study was carried out in three villages, namely Ibrahim Zai, Raisan, and Babar Mela of District Hangu, Khyber Pakhtunkhwa-Pakistan. These are the villages that not only contain both Shia and Sunni communities but have also remained 
the main hub of sectarian clashes. Out of 1010, 279 respondents were randomly selected from the total population under the criteria adopted by (Ullah \& Muhammad, 2020) through the proportional allocation method. The distribution of population and sample size are given in Table 1 below.

Table 1: Sample Size Justifications

\begin{tabular}{lccc}
\hline Villages & Population & Formula & Sample for each Village \\
\hline Ibrahim Zai & 560 & $\mathrm{n} / \mathrm{N}^{*} \mathrm{~N}_{\mathrm{i}}$ & 155 \\
\hline Raisan & 280 & $\mathrm{n} / \mathrm{N}^{*} \mathrm{~N}_{\mathrm{i}}$ & 77 \\
\hline Babar mala & 170 & $\mathrm{n} / \mathrm{N}^{*} \mathrm{~N}_{\mathrm{i}}$ & 47 \\
\hline Total & 1010 & & 279 \\
\hline
\end{tabular}

A semi-structured questionnaire was designed through the Likert scale for data collection. Five questionnaires were piloted in village Ibrahim Zai for checking and testing the validity of the questions and questionnaire for any modification before actual data collection. The conceptual framework was planned with an independent variable (Madrasas' Education, Table 2) and a dependent Variable (Sectarian Violence).

Table 2: Conceptual Framework

\begin{tabular}{lc}
\hline Independent variable & Dependent variable \\
\hline Madrasas' Education & Sectarian Violence \\
\hline
\end{tabular}

The aforementioned variables were operationalized through the following statements. See table 3

Table 3: Operationalization

\begin{tabular}{ll}
\hline Variables & Operationalization \\
\hline Sectarian Violence & 1. Sectarianism negatively affected peace in your area \\
& 2.The prevalence of sectarian violence generate less tolerance among people \\
& 3. Without peace cooperation and coordination among people is difficult to prevail \\
& 4. Good relationship among people is not possible without peace \\
& 5.People of different sects in your area did not cooperate \\
& 6.People have no spirits for doing some welfare activities \\
& 7. People did not tolerate each other's beliefs \\
\hline Madrasas' Education & 1.Religious literature. \\
& 2.Religion is used as a tool for capturing political power \\
& 3.Fatwas of different sects \\
& 4.Contradiction on beliefs among sects. \\
& 5.Every sect tries to implement its ideology in society. \\
& 6.Unregistered madrassa's. \\
& 7.Religious meetings. \\
& 8.Every religious leader tries to preach their ideology in a religious gathering. \\
& 1.Sunni \\
2.Shia \\
\hline Sects & 1.Literate \\
& 2. Illiterate \\
\hline
\end{tabular}

The collected data have been analyzed while using a "statistical package for social science" (SPSS $20^{\text {th }}$ version). The relationship between the dependent and independent variables of the present study was asserted through the Chi-squire test for details see (Ullah et al., 2021; Ullah \& Muhammad, 2020). Before the analysis, the aforementioned variables were indexed.

\section{RESEARCH RESULTS}

Chi-square statistical test was carried out to determine the impact of madrasas' education (independent variable) on sectarian violence (dependent variables). Results show that madrasas' education has a significant role in generating sectarian violence as the observed value of $x^{2}=27.617$ as strongly significant at $1 \%$ level of significance 
Table 4: Association Between Madrasas' Education and Sectarian Violence

\begin{tabular}{lll}
\hline Independent variable & Dependent variable & Statistics \\
\hline Madrasas' Education & Sectarian Violence & $x^{2}=27.617$ \\
& & $p=0.000$ \\
\hline
\end{tabular}

To define variations, in the emergence of sectarian violence caused by madrasas' education was further explored through the statistical analysis of 'literacy' of the survey participants. Findings of the study revealed the relationship between madrasas' education and sectarian violence as significant $(P=\leq 0.05)$ for both groups i.e., literate, and illiterate.

Table 5: Association Between Madrasas’ Education and Sectarian Violence (Controlling Literacy)

\begin{tabular}{llll}
\hline Literacy Level & $\begin{array}{l}\text { Independent } \\
\text { variable }\end{array}$ & Dependent variable & Statistics \\
\hline Illiterate & Madrasas' & Sectarian Violence & $\begin{array}{l}x^{2}=15.919 \\
p=0.003\end{array}$ \\
& Education & & \\
\hline Literate & Madrasas' & Sectarian Violence & $\begin{array}{l}x^{2}=27.866 \\
p=0.000\end{array}$ \\
& Education & & \\
\hline
\end{tabular}

To define variations, the emergence of sectarian violence caused by madrasas' education was also explored by the statistical analysis of 'sect' of the survey participants. Findings of the study revealed the relationship between madrasas' education and sectarian violence as significant $(P=\leq 0.05)$ for the Sunni sect and Non-significant for the Shia sect $(P=\geq 0.05)$.

Table 6: Association Between Madrasas' Education and Sectarian Violence (Controlling Sect)

\begin{tabular}{llll}
\hline Sect & $\begin{array}{l}\text { Independent } \\
\text { variable }\end{array}$ & Dependent variable & Statistics \\
\hline Shia & Madrasas' & Sectarian Violence & $x^{2}=4.267$ \\
& Education & & $p=0.371$ \\
\hline Sunni & Madrasas' & Sectarian Violence & $x^{2}=24.107$ \\
& Education & & $p=0.000$ \\
\hline
\end{tabular}

\section{DISCUSSION}

Religious teaching is considered one of the major components of traditional societies and the main source of socialization. Besides, Religious teaching and beliefs in these societies are a source of unity, however, misinterpretation of religious teaching also generates a massive conflict in the societies. The majority of the people are the main victims of violence in all over the world and instead of extremist behavior, these people are struggling for endorsement of peace. The same is true in Pakistani society because for societal integration, religious injunctions are strictly followed. Notwithstanding, controversial fatwas of sects spreading hate, controversies among sects, and unregistered madrasas are the contributing factors of sectarian violence. The findings of the present study revealed that madrasas' education has a significant role in sectarian violence. These findings are closely in line with the recent study conducted by Ashraf (2019) who explored the misinterpretation of Islamic education by each sect as a cause of the upsurge of sectarian violence in Pakistan. Similarly, Waseem et al. (2010) narrated that sectarian conflicts are accelerated by clergymen and the main ambitions behind this are the achievements of the economic and political goals rather than religious ideologies. Likewise, Ali (2000) explored that in District Jhang, ShiaSunni conflict is not due to religious and ideological differences but often it has seen that the religious leaders take advantage of these kinds of conflict for political power and also to increase their followers and to implement their own ideology as to what they want without any religion interest. At the Multivariate level, results of the study disclosed that madrasas' education has a significant role in sparking sectarian violence for the Sunni sect and non-significant for the Shia sect. However, the existing literature negates these results. For example, the empirical work of $\underline{S}$. V. R. Nasr (2000) disclosed that the religious extremist behaviors of both the sects generate enmity and hatred feelings against each other which is not only limited to speeches but to different controversial materials distributed among different peoples to spark the fire of hatred. Findings of the study revealed that the relationship between madrasas' education and sectarian violence was found significant for both groups i.e., literate, and illiterate. It could be attributed to the fact that the education system failed in the formation of youth attitude towards peaceful society. In addition, sectarian mindset is deeply internalized in Pakistani education system. Similar findings were also concluded by Baytiyeh (2017) that religious school and ineffective education system triggered sectarian based violence in Lebanon.

\section{CONCLUSIONS}

The main aim of this study was to explore the role of religious education that contributed to sectarian violence in the targeted area. It has been affirmed from the study's findings that the phenomenon of sectarian conflict has a complex nature. Religion 
has been used as a tool for capturing political power and leaders promoting conflict among sects. Besides, fatwas against each other sects are some of the contributing factors which lead to hate and controversies among sects. The study found that contradiction in beliefs among sects and misuse of unregistered madrassas have a great contribution in promoting sectarian conflicts in the area because they use their literature for developing extremists' behavior among the masses of the community.

\section{RECOMMENDATIONS FOR POLICYMAKERS}

The study recommends uniformity of madrasa's education including modern education in their syllabus. Besides, registration of madras and also regulating their funding sources is also recommended. Further, the development of underdeveloped areas of Pakistan needs to be focused on. Similarly, cross religion and sects' dialogue should be encouraged. Work on the spread of pluralistic approaches is required. Both Shia and Sunni sects must be dealt with neutrally by state apparatus, particularly avoiding favor to one specific sectarian group.

\section{LIMITATIONS OF THE STUDY}

Consistent with previous empirical findings, this study has the following limitations. The findings of this study focus narrowly on the collected data of District Hangu. Which could affect the generalization of the study. Moreover, this study only evidenced the role of religious education in sectarian violence while other factors like forging policy and socioeconomic factors have not been considered in this study given the limited time. Moreover, due to limited access to the females in the research site, the primary data was collected only from male participants.

\section{ACKNOWLEDGEMENT}

During this study, there was no conflict of interest among co-authors. We declare that all the work presented in this work is solely our own. Further, this study is not supported by any funding agency.

\section{AUTHORS CONTRIBUTION}

The conception and design of the article were presented by Madad Ali. and Aman Ullah. Both authors developed the paper. Seema Zubiar and Sadaf Kalsoom Khattak carried out a statistical analysis. Critical revision of the article for important intellectual content was done by Mahrukh Shakir. Maryam did a lot of work in data collection. All authors discussed the results and contributed to the final manuscript

\section{REFERENCES}

1. Abbas, S. A., \& Syed, S. H. (2020, 2020/09/09/). Sectarian terrorism in Pakistan: Causes, impact and remedies. Journal of Policy Modeling. https://doi.org/10.1016/j.jpolmod.2020.06.004

2. Abou Zahab, M. (2002). The regional dimension of sectarian conflicts in Pakistan. Pakistan: Nationalism without a nation, 115-128.

3. Ahmad, M. (1997). Revivalism, Islamization, sectarianism and violence in Pakistan. Pakistan, 101-123.

4. Ahmed, K. (2013). Sectarian violence in Pakistan. Economic and Political Weekly, 40-42.

5. Ali, M. A. (2000). Sectarian Conflict in Pakistan: A Case Study of Jhang. E. R. Regional Centre for Strategic Studies 2. https://www.rcss.org/publication/policy paper/RCSS\%20Policy\%20Studies\%209.pdf

6. Ashraf, M. A. (2019). Exploring the potential of religious literacy in Pakistani education. Religions, 10(7), 429. https://doi.org/10.3390/rel10070429

7. Bakhsh, R., Khan, S., \& Haider, S. I. (2020). Contesting Sectarian Identity in Pakistan: Narratives from the Three Cities. Global Regional Review, 1, 51-57. https://doi.org/10.31703/grr.2020(V-I).07

8. Baytiyeh, H. (2017). Has the educational system in Lebanon contributed to the growing sectarian divisions? Education and Urban Society, 49(5), 546-559. https://doi.org/10.1177/0013124516645163

9. Berger, P. L. (1954). The sociological study of sectarianism. Social Research, 467-485.

10. Grare, F. (2007, 2007/04/01). The Evolution of Sectarian Conflicts in Pakistan and the Ever-Changing Face of Islamic Violence. South Asia: Journal of South Asian Studies, 30(1), 127-143. https://doi.org/10.1080/008564 00701264068

11. Khalili, E. (2014). Sects in Islam: Sunnis and Shias. Humanities, 1(1), 41-47.

12. Khan, S., \& Chaudhry, H. (2011). Determinants of sectarianism in Pakistan: A Case Study of District Jhang'. Middle-East Journal of Scientific Research, 8(1), 237-243.

13. Khan, Z. (2016). Sectarian Rise in Pakistan: Role of Saudi Arabia and Iran. Researcher in Government and Public Policy, National Defence University, Islamabad, Pakistan.

14. Lynch, M. (2013). The entrepreneurs of cynical sectarianism. POMEPS, POMEPS Studies, 4, 3-6.

15. Mahsood, A. K., \& Muhammad, K. (2017). History of sectarianism in Pakistan: Implications for lasting peace. Journal of Political Sciences \& Public Affairs, 5(4), 2. https://doi.org/10.4172/2332-0761.1000291 
16. Naaz, S. (2019). Emergence Of Sectarian Violence In Pakistan. 4D International Journal of Management and Science, 10(1), 22.

17. Nasr, S. V. R. (2000). The rise of Sunni militancy in Pakistan: The changing role of Islamism and the Ulama in society and politics. Modern Asian Studies, 34(1), 139-180. https://doi.org/10.1017/S0026749X00003565

18. Nasr, V. R. (2000). International Politics, Domestic Imperatives, and Identity Mobilization: Sectarianism in Pakistan, 1979-1998. Comparative Politics, 171-190. https://doi.org/10.2307/422396

19. Phillips, C. (2015). Sectarianism and conflict in Syria. Third World Quarterly, 36(2), 357-376. https://doi.org/10.1080/01436597.2015.1015788

20. Roberts, K. A., \& Yamane, D. (2015). Religion in sociological perspective. Sage Publications.

21. Shah, M. N. (2014). Evolution of sectarianism in Pakistan: A threat to the state and society. South Asian Studies A Research Journal of South Asian Studies, 29(2), 441-459.

22. Smith, C. (2014). Disruptive religion: The force of faith in social movement activism. Routledge. https://doi.org $/ 10.4324 / 9781315022147$

23. Ullah, A., Ashraf, H., Tariq, M., Aziz, S. Z., Sikandar, K. U. R., Ali, N., Shakoor, A., \& Nisar, M. (2021). Battling the Invisible Infertility Agony: A Case Study of Infertile Women in Khyber Pakhtunkhwa-Pakistan. Journal of Ethnic and Cultural Studies, 8(2), 89-105. https://doi.org/10.29333/ejecs/679

24. Ullah, A., \& Muhammad, N. (2020). Prevalence of mental health problems among youth involved in street crimes. Rawal Medical Journal, 45(4), 938-942.

25. Ullah, S., Guoqiang, H., Khan, U., \& Niazi, K. (2020). State, religion and the marginalisation of traditional healing in Gwadar, Pakistan. Medical Humanities, 46(4), 444-453. https://doi.org/10.1136/medhum-2019-011747

26. Waseem, M., Kamran, T., Ali, M. A., \& Riikonen, K. (2010). Dilemmas of pride and pain: sectarian conflict and conflict transformation in Pakistan.

27. Zaman, M. Q. (1998). Sectarianism in Pakistan: The radicalization of Shi'i and Sunni identities. Modern Asian Studies, 32(3), 689-716. https://doi.org/10.1017/S0026749X98003217 